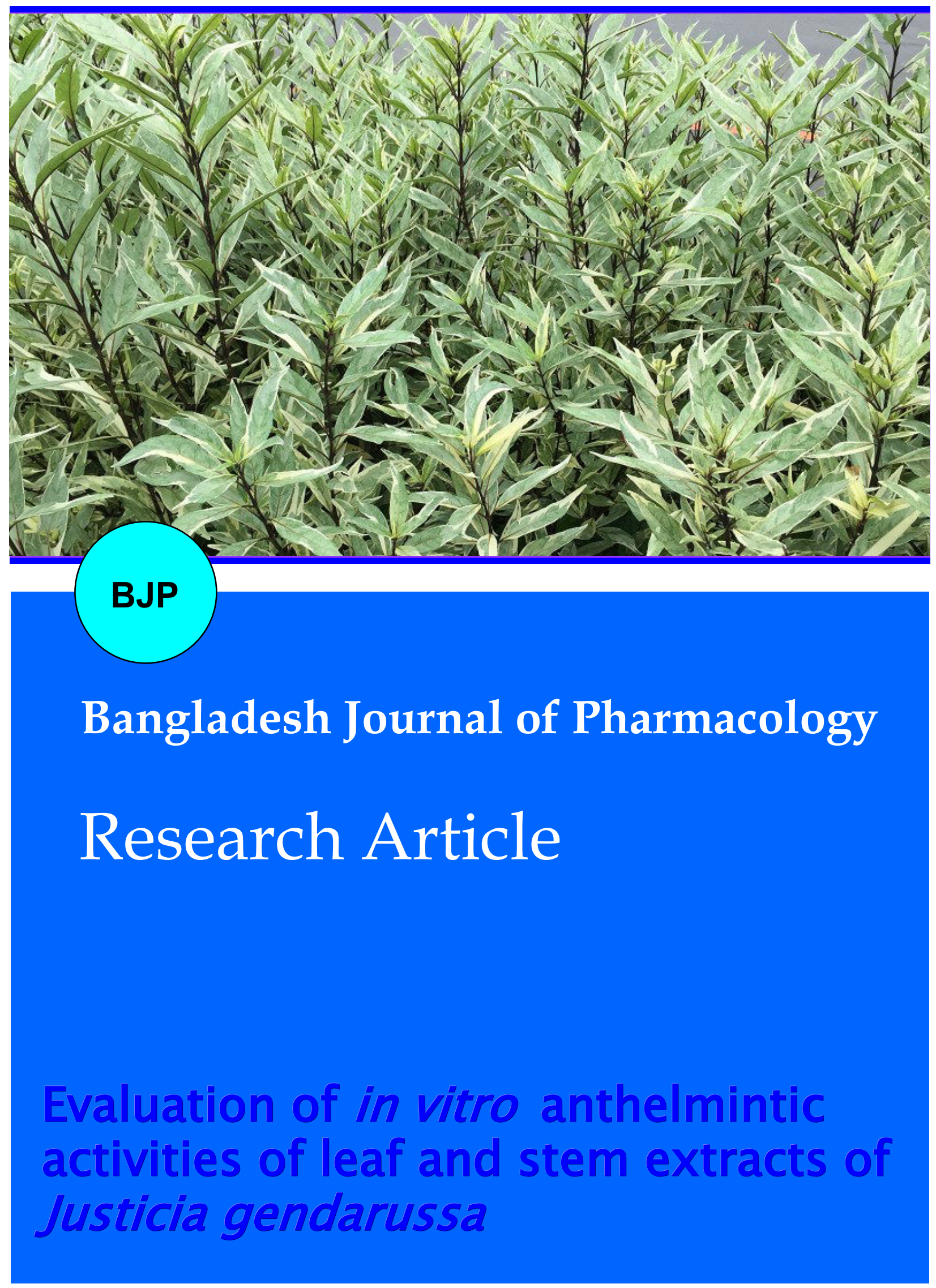


Abstracted/indexed in Academic Search Complete, Asia Journals Online, Bangladesh Journals Online, Biological Abstracts, BIOSIS Previews, CAB Abstracts, Current Abstracts, Directory of Open Access Journals, EMBASE/Excerpta Medica, Google Scholar, HINARI (WHO), International Pharmaceutical Abstracts, Open J-gate, Science Citation Index Expanded, SCOPUS and Social Sciences Citation Index;

ISSN: $1991-0088$

\title{
Evaluation of in vitro anthelmintic activities of leaf and stem extracts of Justicia gendarussa
}

\author{
Monika Rani Saha', Pankaj Chandra Debnath ${ }^{1}$, Md. Ajijur Rahman ${ }^{2}$ and \\ Md. Anwar Ul Islam² \\ ${ }^{1}$ Department of Pharmacy, Noakhali Science and Technology University, Noakhali, Bangladesh; ${ }^{2}$ Department of \\ Pharmacy, University of Rajshahi, Rajshahi 6205, Bangladesh.
}

\begin{tabular}{|c|c|}
\hline Article Info & \\
\hline Received: & 3 April 2012 \\
\hline Accepted: & 9 May 2012 \\
\hline Available Online: & 13 May 2012 \\
\hline DOI: $10.3329 /$ bjp. & 0558 \\
\hline $\begin{array}{l}\text { Cite this article: } \\
\text { Saha MR, Debnat } \\
\text { Islam MAU. Eva } \\
\text { anthelmintic acti } \\
\text { stem extracts of } \\
\text { Bangladesh J Pha } \\
53 \text {. }\end{array}$ & $\begin{array}{l}\text { Rahman MA, } \\
n \text { of in vitro } \\
\text { of leaf and } \\
\text { ia gendarussa. } \\
\text { l. 2012; 7: 50- }\end{array}$ \\
\hline
\end{tabular}

\begin{abstract}
This present study explored the anthelmintic activities of crude methanolic extract of dried leaves and stems of Justicia gendarussa, an evergreen plant belonging to the family Acanthaceae. This plant is commonly known as Bishjarul in Bangladesh. Five concentrations (10, 20, 30, 40 and $50 \mathrm{mg} / \mathrm{mL}$ ) of each extract were studied in the bioassay to determine the paralysis time and death time of the worm, Pheretima posthuma. Methanolic extract of leaves (50 $\mathrm{mg} / \mathrm{mL}$ ) caused paralysis of the worms at $35.3 \mathrm{~min}$ and death at $70.7 \mathrm{~min}$ while methanolic extract of stem of J. gendarussa caused paralysis at $41.3 \mathrm{~min}$ and death at $89.3 \mathrm{~min}$. Albendazole (positive control) paralyzed and killed the worms at 17 and $48 \mathrm{~min}$, respectively. The study confirms the significant anthelmintic activities of leaves and stems extract of J. gendarussa and therefore demands the isolation of active principles thorough bioassay. This is the first report of anthelmintic activities of J.gendarussa.
\end{abstract}

\section{Introduction}

Nature always acts as a great source of salvation for human being by providing different remedies from its plants, animals, and other sources to cure all ailments of mankind (Dubey et al, 2004). Medicinal plants provide affordable means of health care for poor and marginalized people. But they are also potential sources of many therapeutic active compounds. The universal role of plants in the treatment of diseases is established by their employment in all important systems of medicine. There are many plants which has been unexplored in the field of medicine or science (Reddy et al, 2010). Because of such great opportunities in medicinal plants, continuous approaches are going on to isolate various therapeutically active compounds. Many active drugs have been derived from different medicinal plants, and the process is going on. According to an analysis, 23 new drugs derived from natural sources have been launched on the market during 2000-05 (Chin et al,
2006). Besides new drugs launched on the market from 2000 to the present, there are a variety of new chemical entities from natural sources undergoing clinical trials.

Justica gendarussa Burm (Family- Acanthaceae, English name, Black adusa) is a shade loving, quick growing, evergreen shrub found throughout India and also in all Asian countries like Malaysia, Indonesia, Sri Lanka and Bangladesh (Rantnasooriya et al, 2007). The plant is used traditionally for the treatment of chronic rheumatism, inflammations, bronchitis, vaginal discharges, dyspepsia, eye diseases and fever (Rantnasooriya et al., 2007; Mrunthunjaya, 2007). Justicia has been found to contain lignans, naturally occurring phenolic dimmers (Mrunthunjaya, 2007) and triterpenoids (Chakravarty et al., 1982). In Bangladesh, it is not cultivated but found in almost everywhere. Uddin and his co-workers (2011) reported the isolation of stigmasterol, lupeol and 16 hydroxylupeol from a methanol extract of J. gendarussa. They also reported the anti-oxidant, anti-microbial and 


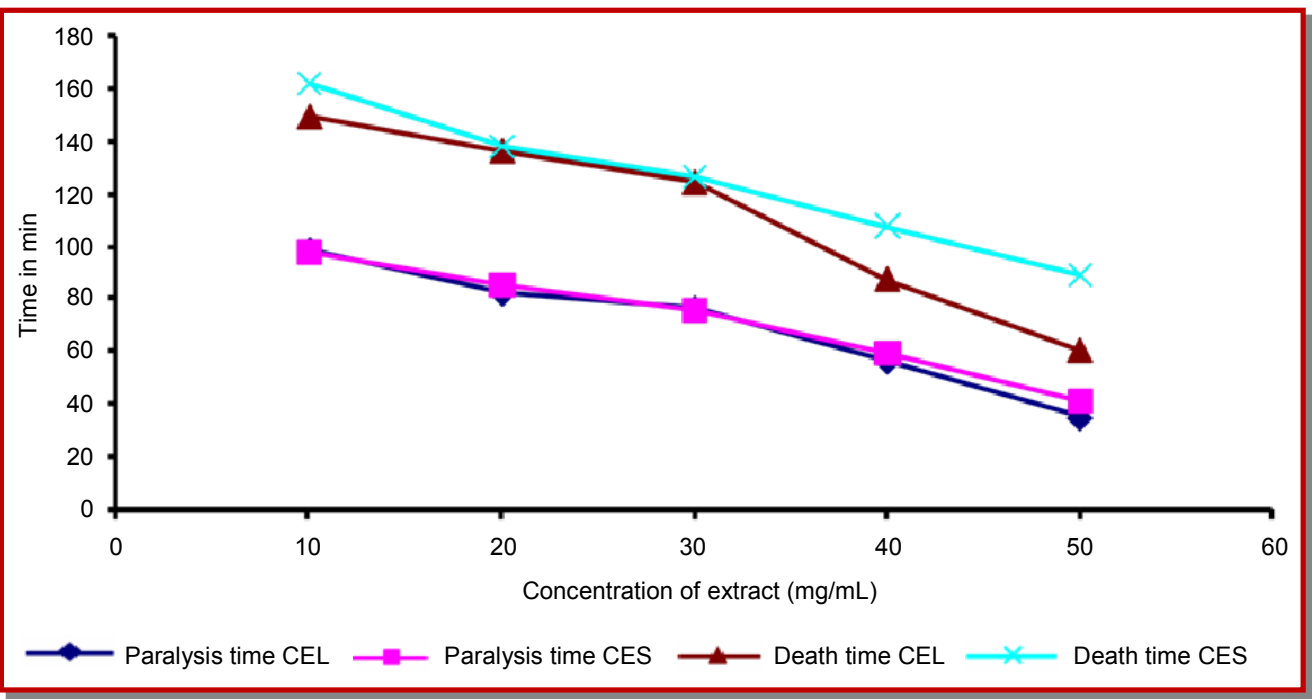

Figure 1: Plot of concentration of plant extractives versus paralysis time and death time of Pheretima posthuma. Where, CEL: Crude methanolic extract of leaves; CES: Crude methanolic extract of stem

\begin{tabular}{|c|c|c|c|c|c|c|c|}
\hline & & & & & & & \\
\hline Antheln & activity 0 & e methan & $\begin{array}{r}\text { extracts of } \\
m a p\end{array}$ & $\begin{array}{l}\text { es and ste } \\
\text { uma }\end{array}$ & of Justicio & udarussa ag & st Phereti- \\
\hline Conc. & & Paralysi & e $(\mathrm{min})$ & & & Albendazole & \\
\hline$(\mathrm{mg} / \mathrm{mL})$ & CEL & CES & CEL & CES & $\begin{array}{c}\text { Conc. } \\
\text { (mg/mL) }\end{array}$ & $\begin{array}{l}\text { Paralysis } \\
\text { time (min) }\end{array}$ & $\begin{array}{l}\text { Death time } \\
\text { (min) }\end{array}$ \\
\hline 10 & $98.7 \pm 0.7$ & $97.7 \pm 0.5$ & $149.3 \pm 0.7$ & $161.7 \pm 0.5$ & 10 & $17.7 \pm 0.5$ & $48 \pm 0.5$ \\
\hline 20 & $82.3 \pm 0.7$ & $85.3 \pm 0.7$ & $136.3 \pm 0.7$ & $137.7 \pm 0.5$ & & & \\
\hline 30 & $76.7 \pm 0.7$ & $75.7 \pm 0.7$ & $124.3 \pm 0.5$ & $126.7 \pm 0.7$ & & & \\
\hline 40 & $56.7 \pm 0.7$ & $59.7 \pm 0.7$ & $87.7 \pm 0.7$ & $107.7 \pm 0.7$ & & & \\
\hline 50 & $35.3 \pm 0.7$ & $41.3 \pm 0.7$ & $70.7 \pm 0.3$ & $89.3 \pm 1.0$ & & & \\
\hline
\end{tabular}

Values are expressed as mean \pm SEM $(n=3)$. CEL: Crude methanolic extract of leaves; CES: Crude methanolic extract of stem

cytotoxic properties of the various extractives of the whole plant for the first time. However, so far no study has been conducted to determine the anthelmintic potential of J. gendarussa. In the present study, leaves and stems of J. gendarussa were extracted with methanol and the extractives were investigated for their anthelmintic activities.

\section{Materials and Methods}

\section{Collection and identification of the plant}

The plant sample of J. gendarussa was collected from the Noakhali district, Bangladesh in June 2011. The plant was identified and a voucher specimen (Accession number DACB: 36060) representing this collection has been deposited in the Bangladesh National Herbarium, Dhaka, for further reference.

\section{Preparation, extraction and fractionation of plant material}

The dried and powdered leaves and stems (500 g) were extracted with methanol with occasional shaking and stirring for 7 days. The whole extract was filtered and the solvent was evaporated and a semisolid mass of 30 $\mathrm{g}$ and $25 \mathrm{~g}$ for leaves and stems were obtained, respectively.

\section{In vitro anthelmintic activity}

The anthelmintic assay was carried out as per the method of Ajaiyeoba et al. (2001) with minor modifications. Adult earthworms were used to study the anthelmintic activity due to its anatomical and physiological resemblance with the intestinal roundworm parasites of human being (Vidyarthi, 1967; Thorn et al., 1977; Vigar, 1984; Chatterjee, 1967; Kumar BSA et al., 2010; Kumar et al., 2010). Because of availability of earthworms, they are widely used as effective tools for anthelmintic study (Sollmann, 1918; Jain et al., 1972; Szewezuk et al., 2003; Dash et al., 2002). Adult earthworm (Pheretima posthuma) were collected $(3-5 \mathrm{~cm}$ in length and 0.1-0.2 cm in width weighing about 0.8 $3.04 \mathrm{~g}$ ) from moist soil of a road side canal of Noakhali Science and Technology University, Sonapur, Noakhali. All the worms were washed with normal saline to remove all fecal matters. Extracts were weighed and 
dissolved in $10 \mathrm{~mL}$ of distilled water to obtain the concentrations of 10, 20, 30, 40 and $50 \mathrm{mg} / \mathrm{mL}$. Albendazole was used as reference standard $(10 \mathrm{mg} / \mathrm{mL})$. Earthworms were divided into twelve groups (each containing three) in petri dish. Extract of leaves and stems were applied to the petri dishes and observations were made for determining paralysis time and death time of the worm. Paralysis was said to occur when the worms do not move even in normal saline. Death was confirmed when the worms lose their motility followed with fading away of their body color.

\section{Results}

The crude methanolic extracts of leaves and stems of Justicia gendarussa were used to evaluate anthelmintic activities. As shown in the Figure 1 and Table I, crude methanol extract of leaves of J. gendarussa showed significant anthelmintic activity at the concentration of 10 , 20, 30, 40 and $50 \mathrm{mg} / \mathrm{mL}$ in a dose-dependant manner giving shortest time of paralysis and death time at 50 $\mathrm{mg} / \mathrm{mL}$.

The crude methanol extract of stem also exhibited significant anthelmintic property at dose of $50 \mathrm{mg} / \mathrm{mL}$. Methanolic extract of leaves of J. gendarussa at concentration of $50 \mathrm{mg} / \mathrm{mL}$ caused paralysis of Pheretima posthuma at $35.3 \mathrm{~min}$ and death at $70.7 \mathrm{~min}$ while the methanolic extract of stem at the same concentration caused paralysis at $41.3 \mathrm{~min}$ and death at $89.3 \mathrm{~min}$. Albendazole (positive control) caused paralysis and death at 17 and $48 \mathrm{~min}$, respectively at $10 \mathrm{mg} / \mathrm{mL}$.

\section{Discussion}

Cytotoxic activities of various fractions of the whole plant extract of J. gendarussa have been described by Uddin et al. (2011). According to their observation, the petroleum ether soluble materials of whole plant demonstrated highest toxicity with $\mathrm{LC}_{50}$ value of 1.3 $\mu \mathrm{g} / \mathrm{mL}$. This was the first report of isolation of compounds from J. gendarussa and its anti-oxidant, antimicrobial and cytotoxic properties. We also found that the chloroform fractions of both stem and leaves were more toxic than petroleum ether fractions. The $\mathrm{LC}_{50}$ values of chloroform fractions of leaves and stem were 0.7 and $1.8 \mu \mathrm{g} / \mathrm{mL}$, respectively, whereas, for petroleum ether fractions the values were 1.1 and $2.7 \mu \mathrm{g} / \mathrm{mL}$ (data not shown).

Antihelminthic activities of J. gendarussa have not been studied before. Adult earthworms (Pheretima posthuma) were used in this study to determine the anthelmintic activity due to their anatomical and physiological resemblance with the intestinal roundworm parasites of human being (Vidyarthi, 1967; Thorn et al., 1977; Vigar, 1984; Chatterjee, 1967; Kumar et al., 2010; Kumar et al.,
2010). Most of in vitro experiments regarding anthelmintic activity of plants have been based on their toxic effects on this earthworm (Gaind et al., 1967; Ali et al., 1970; Kokate et al., 1971; Dixit et al., 1975; Banerjee et al., 1978; Girgune et al., 1978; Agarwal et al., 1979; Girgune et al., 1979; Mishra et al., 1979; Mehta et al., 1981; Garg et al., 1982, Dengre, 1982; Nanda et al., 1987; Siddiqui et al., 1990; Garg et al., 1992). It has been demonstrated that all anthelmintic are toxic to earthworms and a substance toxic to earthworms is worthy for investigation as an anthelmintic (Sollmann, 1918). We used albendazole was used as positive control. The crude extracts of stem and leaves of J. gendarussa exhibited significant anthelmintic activities. At $50 \mathrm{mg} / \mathrm{mL}$ concentration, the methanolic crude extracts of leaves and stem caused death of Pheretima posthuma at 60 and 89 min, respectively.

As studied previously by Uddin et al. (2011), the plant contains stigmasterol, lupeol and 16-hydroxylupeol in the methanol extract which may be responsible for the anthelmintic activities of this plant. However, further study should be carried out to determine the compounds present in the methanolic extract. In vivo study using animal model may also be used to determine the possible antitumor activities of the extracts. Now our next aim is to explore the compounds liable for aforementioned activity from this plant.

\section{Acknowledgement}

The authors would like to thank the Chairman, Department of Pharmacy, Noakhali Science and Technology University, Noakhali, Bangladesh for providing laboratory facilities to conduct the research.

\section{References}

Agarwal R, Kharya MD, Srivastava R. Anti-microbial and anthelmintic activities of the essential oil of Nigella sativa Linn. Indian J Expt Biol. 1979; 17: 1264

Ajaiyeoba EO, Onocha PA, Olarenwaju OT. In vitro anthelmintic properties of Buchholzia coriaceae and Gynandropsis gynandries extract. Pharm Biol. 2001; 39: 217-20.

Akhtar MS, Iqbal Z, Khan MN, Lateef M. Anthelmintic activity of medicinal plants with particular reference to their use in animals in Indo-Pakistan subcontinent. Small Ruminants Res. 2000; 38: 99-107.

Ali SM, Mehta RK. Preliminary pharmacological and anthelmintic studies of the essential oil of Piper betle L. Indian J Pharm. 1970; 32: 132-33.

Banerjee A, Nigam SS. In vitro anthelmintic activity of the essential oils derived from the various species of the genus Curcuma. Sci Cult. 1978; 44: 503-04.

Chakravarty AJ, Dastidar PPG, Pakrashi SC. Simple aromatic amines from Justicia Gendarussa: 13C NMR Spectra of the bases and their analogues. Tetrahedron 1982; 38: 1797-802. 
Chatterjee KD. Parasitology, protozoology and helminthology. 6th ed. Calcutta, Guha Ray Sree Saraswaty Press Ltd, 1967.

Chin YW, Balunas MJ, Chai HB, Kinghorn AD. Drug discovery from natural sources. AAPS J. 2006; 8: E239-53.

Dash GK, Suresh P, Kar DM, Ganpaty S, Panda SB. Evaluation of Evolvulus alsinoids Linnb for anthelmintic and antimicrobial activities. J Nat Rem. 2002; 2: 182-85.

Dengre SL. Chemical and physiological examination of essential oils from Indian sources. Ph.D. Thesis. Dr. Hari Singh Gour Vishwavidyalaya, Sagar, India, 1982, pp 171-79.

Dixit VK, Varma KC. Anthelmintic properties of essential oils from rhizomes of Hedychium coronarium Koenig and Hedychium spicatum Koenig. Indian J Pharm. 1975; 37: 143-44.

Dubey NK, Kumar R, Tripathi P. Global promotion of herbal medicine: India's opportunity. Curr Sci. 2004; 86: 37-41.

Gaind KN, Budhiraja RD. Antibacterial and anthelmintic activity of Withania coagulans Dunal. Indian J Pharm. 1967; 29: $185-86$.

Garg SC, Kasera HL. Anthelmintic activity of Callistemon viminalis. Fitoterapia 1982; 53: 179-81.

Garg SC, Nakhare S. Studies on the essential oils from the flowers of Eupatorium triplinerve. Indian Perfumer. 1993; 37: $318-23$.

Garg SC, Siddiqui N. Anthelmintic activity of Vernonia teres L. and Clerodendrum phlomidis. J Res Edu Indian Med. 1992; 11: $1-3$.

Garg SC, Kasera HL. In vitro anthelmintic activity of the essential oil of Anacardium occidentale. Indian Perfumer. 1982; 26: $239-40$.

Geert S, Dorny P. Anthelmintic resistance in helminthes of animals of man in the tropics. Bulletin-des-Seances, Academic-Royale-des-Sciencesd. 1995; 3: 401-23.

Girgune JB, Jain NK, Garg BD. Anti-microbial and anthelmintic activity of essential oil from Gardenia lucida Roxb. Indian Perfumer. 1979; 23: 213-15.

Girgune JB, Jain NK, Garg B. Anthelmintic activity of some essential oils. Indian Perfumer. 1978; 22: 296-97.

Jain ML, Jain SR. Therapeutic Utility of Ocimum basilicum var. album. Planta Medica. 1972; 22: 66-70

Kokate CK, Varma KC. Anthelmintic activity of some essential oils. Indian J Hosp Pharm. 1971; 8: 150-51.

Kumar A, Lakshman K, Jayaveera KN, Nandeesh R, Manoj B, Ranganayakulu D. Comparative in vitro anthelmintic activity of three plants from the Amaranthaceae family. Archives Biol Sci. 2010; 62: 185-89.

Kumar BSA, Lakshman K, Jayaveera KN, Velmurugan C, Manoj B, Sridhar SM. Anthelmintic activity of methanol extract of Amaranthus caudatus Linn. Internet J Food Safety. 2010; $12: 127-29$.

Lewis WH, Lewis. Medicinal botany plants affecting man's health. New York, John Wiley \& Sons, 1977.

Marley CL. The effect of dietary forage on the development and survival of helminth parasites in ovine faeces. Vet Parasitol. 2003; 118: 93-107.

Mehta MB, Kharya MD, Srivastava R, Varma KC. Antimicrobial and anthelmintic activities of the essential oil of Zanthoxylurn alatum Roxb. Indian Perfumer. 1981; 25: 1-3.

Mishra SH, Gaud RS, Sharma RA, Chaturvedi SC. Anthelmintic activity of some essential oils. Indian Perfumer. 1979; 23: 208-09.

Mrunthunjaya K, Hukkeri VI. Anti-oxidant and free radical scavenging potential of $J$. gendarussa Burm, leaves in vitro. Nat Prod Sci. 2007; 3: 199-206.

Nadkarni AK. Indian Materia Medica. 3rd ed. Bombay, Popular Prakashan, 1954.

Nanda A, Iyengar MA, Narayan CS, Kalkarni DR. Investigations on the root bark of Aglaia odoratissima. Fitoterapia 1987; 58: 189-91.

Niezen JH, Waghorn TS, Charleston WAG, Waghorn GC. Growth and gastrointestinal nematode parasitism in lambs grazing either lucerne (Medicago sativa) or sulla (Hedysarum coronarium) which contain condensed tannins. J Agric Sci. 1995; 125: 281-89.

Rantnasooriya WD, Derianyagala SA, Dehigas DC. Antinociceptive activity and toxicological study of aqueous leaves extract of J gendarussa. Phcog Mag. 2007; 3: 145-55.

Reddy LJ, Jose B, Anjana JC, Ruveena TN. Evaluation of antibacterial activity of Trichosanthes Cucumerina L. and Cassia didymobotrya Fresh leaves. Int J Pharm Pharm Sci. 2010; 2: 153-55.

Said M. Hamdard Pharmacopea of Eastern Medicine. Karachi, Hamdard National Foundation, 1969.

Satyavati GV, Raina MK, Sharma M. Medicinal plants of India. New Delhi, Indian Council of Medical Research, 1976, pp 201 -06 .

Siddiqui N, Garg S. In vitro anthelmintic activity of some essential oils. Pakistan J Sci Indust Res. 1990; 33: 536-37.

Sollman T. Anthelmintic: Their efficacy as tested on earthworms. J Pharmacol Exp Ther. 1918; 112: 129-70.

Szewezuk VD, Mongelli ER, Pomilio AB. Antiparasitic activity of Melia azadirach growing in Argentina. Molecular Med Chem. 2003; 1: 54-57.

Thorn GW, Adams RD, Braunwald E, Isselbacher KJ, Petersdorf RG. Harrison's Principles of internal medicine. New York, McGraw Hill Co., 1977.

Uddin MR, Sinha S, Hossain MA, Kaisar MA, Hossain MK, Rashid MA. Chemical and biological investigations of Justicia gendarussa (Burm. f). Dhaka Univ J Pharm Sci. 2011; 10: 53-57.

Vidyarthi RD. A textbook of Zoology. 14th ed. New Delhi, S. Chand and Co, 1967.
Author Info
Md. Ajijur Rahman (Principal contact)
e-mail: ajijur2009@gmail.com 